Оригинальная статья / Original paper

\title{
Stanislav Voronin's Universal Classification of Onomatopoeic Words: a Critical Approach (Part 2)
}

\author{
Maria A. Flaksman ${ }^{\bowtie}$ \\ Saint Petersburg Electrotechnical University, St Petersburg, Russia

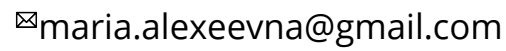

Introduction. The present paper is a critical study of the classification methodology introduced by S. V. Voronin in 1969. The phonosemantic classification of onomatopoeic (sound imitative) words has been tested on the material of typologically different languages and, in general, has proven itself successful. However, the bulk of empirical evidence calls for minor updates on the classification. The first part of the article contained a detailed description of the classification and a critical analysis of its various aspects. This (the second) part contains suggestions as how to overcome the highlighted difficulties.

Methodology and sources. The method applied in the classification is the method of phonosemantic analysis which was introduced by S. V. Voronin. The present article explores the possibilities of its application on data from English and other relevant languages.

Results and discussion. The critical analysis of the universal classification of the onomatopoeic words conducted in the first part of the article revealed the presence of several overlapping classes and hyperclasses, as well as other minor inconsistencies. The introduction of additional hyper-classes and re-classification of frequentatives helps to overcome these difficulties. Thus, I move frequentatives-instants and frequentativescontinuants from the class "frequentatives" to form a hyper-class of their own, leaving what were Voronin's "pure" frequentatives in the former class of frequentatives. I also introduce poly-syllabic onomatopoeic words into the classification.

Conclusion. The introduced changes do not not undermine the key principles of the Universal classification formulated by S. V. Voronin but help its practical implementation on the material of typologically different languages.

Keywords: onomatopoeia, universal classification of onomatopoeic words, iconicity, phonosemantics, language universals, S. V. Voronin.

For citation: Flaksman M. A. Stanislav Voronin's Universal Classification of Onomatopoeic Words: a Critical Approach (Part 2). DISCOURSE. 2021, vol. 7, no. 1, pp. 92-102. DOI: 10.32603/2412-85622021-7-1-92-102

Conflict of interest. No conflicts of interest related to this publication were reported. 


\title{
Универсальная классификация ономатопов С. В. Воронина: критическое осмысление (часть 2)
}

\author{
М. А. Флаксман \\ Санкт-Петербургский государственный электротехнический университет «ЛЭтИ» \\ им. В. И. Ульянова (Ленина), Санкт-Петербург, Россия

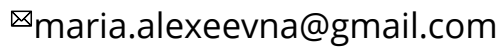

\begin{abstract}
Введение. Настоящая статья посвящена критическому осмыслению Универсальной класиификации ономатопов, разработанной С. В. Ворониным в 1969 г. За последующие годы классификация была применена к обширному материалу родственных и неродственных языков и в целом оказалась успешной. Однако накопленный языковой материал требует дальнейшей переработки классификации, чему и посвящена настоящая статья. В первой части была представлена сама классификация, во второй (настоящей) части статьи предлагаются возможные решения обозначенных проблем.

Методология и источники. Универсальная классификация ономатопов (звукоподражательных слов) основывается на методе фоносемантического анализа, предложенном С. В. Ворониным. В настоящей статье приводятся эмпирические данные английского и других языков, необходимые для иллюстрации выдвигаемых положений и предложений по исправлению используемой методологии.
\end{abstract}

Результаты и обсуждение. Подробное рассмотрение классификации, проведенное в первой части статьи, позволило определить ее спорные места, в частности, выявить пересекающиеся классы и гиперклассы. Введение новых, дополнительных гиперклассов, с нашей точки зрения, позволяет снять обнаруженные противоречия. Так, выведение фреквентативов-инстантов и фреквентативов-континуантов из класса «фреквентативы» (и превращение их в самостоятельные гиперклассы) оставляет в классе только «чистые» фреквентативы (по Воронину), что позволяет избежать упомянутых проблем. Также в статье впервые рассматриваются многосложные звукоподражательные слова.

Заключение. Внесенные изменения не нарушают принципов Универсальной классификации, разработанной С. В. Ворониным, а лишь вносят некоторые дополнения в нее и имеют целью упрощение ее практического применения к материалу типологически отличающихся языков.

Ключевые слова: звукоподражания, универсальная классификация ономатопов, иконичность, фоносемантика, языковые универсалии, С. В. Воронин.

Для цитирования: Флаксман М.А. Универсальная классификация ономатопов С. В. Воронина: критическое осмысление (часть 2) // ДИСКУРС. 2021. Т. 7, № 1. С. 92-102. DOІ: 10.32603/2412-8562-2021-7-1-92-102

Конфликт интересов. О конфликте интересов, связанном с данной статьей, не сообщалось.

Поступила 03.06.2020; принята после рецензирования 15.07.2020; опубликована онлайн 25.02.2021

Introduction. The first part of the article was devoted to the introduction of the Universal Classification of onomatopoeic words (UCO) by S. V. Voronin and to the discussions of its limitations. Part 2 of the article is devoted to possible solutions of the indicated problems.

The main ten problems detected in Part 1 of this paper are:

1. Place of frequentatives in the classification. Frequentatives as a class render "a rapid series of pulses where each pulse is hardly perceived separately yet there is no complete fusion 
of pulses into one tone" [1, p. 53]. In order to be classified as a class (according to the principles of the classification) they should convey "simple sounds" [1, p. 43]. Thus, theoretically, frequentatives describe "harsh, dissonant sounds" via use of (trilled) R [1, p. 53], yet Voronin's frequentatives include also elements of the adjacent classes of instants and continuants [ibid.].

2. Definition of "pure" frequentatives. According to Voronin [1, p. 54], "pure" frequentatives are a sub-class of frequentatives, yet their structural models include plosives (elements of instants). Also, English and Indonesian structural models for "pure" frequentatives differ considerably.

3. Frequentatives and $R$-formatives. Some structural models for frequentatives include R-formatives (which are expressive affixes added to the root). This undermines one of the key principles of the classification - only the roots of imitative words should be classified, as affixes may have their own (expressive, onomatopoeic) function. The -er suffix in question, in particular, conveys iterative (repetitive) meaning.

4. Structural models are language-specific and reflect phonotactic conventions of a language (applied to monosyllabic words). Our previous research [2] has shown that structural models of onomatopoeic words are not diachronically stable and reflect only current inventory and phonotactic constraints of a language.

5. Structural models change in diachrony - see problem 4.

6. Unnecessary large number of types and structural models which complicates the classification. Some of the models proposed for English describe only one word, e. g. model 18 [1, p. 66], which complicates the implementation of the classification.

7. The role of the affricates in the classification. Affricates hold an intermediary position between stops and fricatives and their phonosemantic function by sound imitation is not clear.

8. The role of the sonants, laterals and approximants in the classification. These types of phonemes appear in various models and do not seem to have their own imitative function.

9. The role of voice in the classification. The voiced / voiceless opposition is considered to be meaningful in certain types of structural models, whereas ignored in other types.

10. Vowel length as a distinctive feature of tonal continuants. This quality of vowels is not universal. Even in English the short / long opposition of vowels is only historical. Thus, a very specific phonemic feature is used for a universal classification.

These were the problems discussed in Part 1 of the article. Part 2 is devoted to the possible solutions to these problems.

Methodology and sources. In order to solve the abovementioned problems, I use the same methodological approach as the author of the classification [1]. The phonosemantic approach is based on the principle of iconic relation of onomatopoeic words to their (psycho)-acoustic denotata. The main purpose of the UCO is to reveal the principal acoustic parameters (properties) of sound-denotata which define the choice of type of phonemes comprising an onomatopoeic word [1, p. 39].

S. V. Voronin defines five main parameters of acoustic denotata [1, p. 40]: pitch, volume, time, periodicity, and dissonance quality. These five parameters together give three distinct types of sound denotata: A. Pulses, B. Non-pulses (tones and noises), and C. Dissonances.

The phonemes comprising onomatopoeic words in order to have an imitative function should possess (psycho)-acoustic characteristics closest to these three "poles". If these characteristics match, imitation takes place. 
In this paper we use the phonosemantic approach introduced by Voronin [1] to analyze the “Universal classification”. I draw my examples from the 1500-word Appendix to [2].

\section{Results and discussion.}

\section{Possible solutions to the detected problems.}

The ten major and minor problems listed in the Part 1 and briefly summed up in the Introduction do not undermine the key principles of the UCO formulated by Voronin [1]. What Voronin came across in his research seems to be the following:

- the universal [to much extent diagrammatic] correspondence between types of contrast acoustic denotata (pulse | non-pulse (tone and noise) $\mid$ dissonance) and contrast types of phonemes (plosives I sonorants or vowels / fricatives I trills);

- the primary role of the manner of articulation (of consonants) in imitation of acoustic phenomena (this point has never been postulated in [1] although implied); and the (to much extent) secondary but still important role of voice (manifested via vowels, sonorants, voiced fricatives etc.);

- the limiting role of inventory and phonotactic constraints in onomatopoeia (again, not discussed directly in [1] but meticulously illustrated on numerous structural models for onomatopoeic systems of languages from different language families by the author himself [1-3] as well as those who applied the UCO to the material of other languages [4-8]).

In my opinion, these are the strong points of the classification and of the Voronin's approach to onomatopoeia on the whole. The majority of the described problems seem to originate from the over-fragmentation tendency characteristic of the classification in general.

Thus, the possible solutions I propose are solutions based on unification and re-grouping rather than on challenging the basic principles of the UCO.

The problems 1-3 are the interrelated problems concerning the place of the frequentatives in the classification and the form(s) they take. To solve these problems, let's go back to the principles of classification formulated in [1, p. 42].

The basis of the UCO is the distinction of three both acoustically and psycho-acoustically simple types of acoustic denotata:
A. Pulse;
B. Non-pulse (tone or noise);
C. Dissonance.

The three corresponding classes of onomatopoeic words are:
A. Instants;
B. Continuants (tone or noise);
C. Frequentatives.

All other sounds are acoustically complex entities combined of the three simple contrast elements, and all other onomatopoeic words, thus, belong to (complex) hyper-classes.

According to Voronin [1, p. 44] there are two hyper-classes:

AB. Instants-Continuants;

CAB. Frequentatives-Instants-Continuants (see Fig. 1 in Part 1).

What I propose is distinguishing alongside three classes not two but four hyper-classes (see Fig., this article): 
AB. Instants-Continuants;

AC. Frequentatives-Instants;

BC. Frequentatives-Continuants;

ABC. Frequentatives-Instants-Continuants.

ONOMATOPOEIC WORDS

PLOS+FRIC, FRIC+PLOS, PLOS+SON, SON+PLOS

AB. INSTANTS-CONTINUANTS

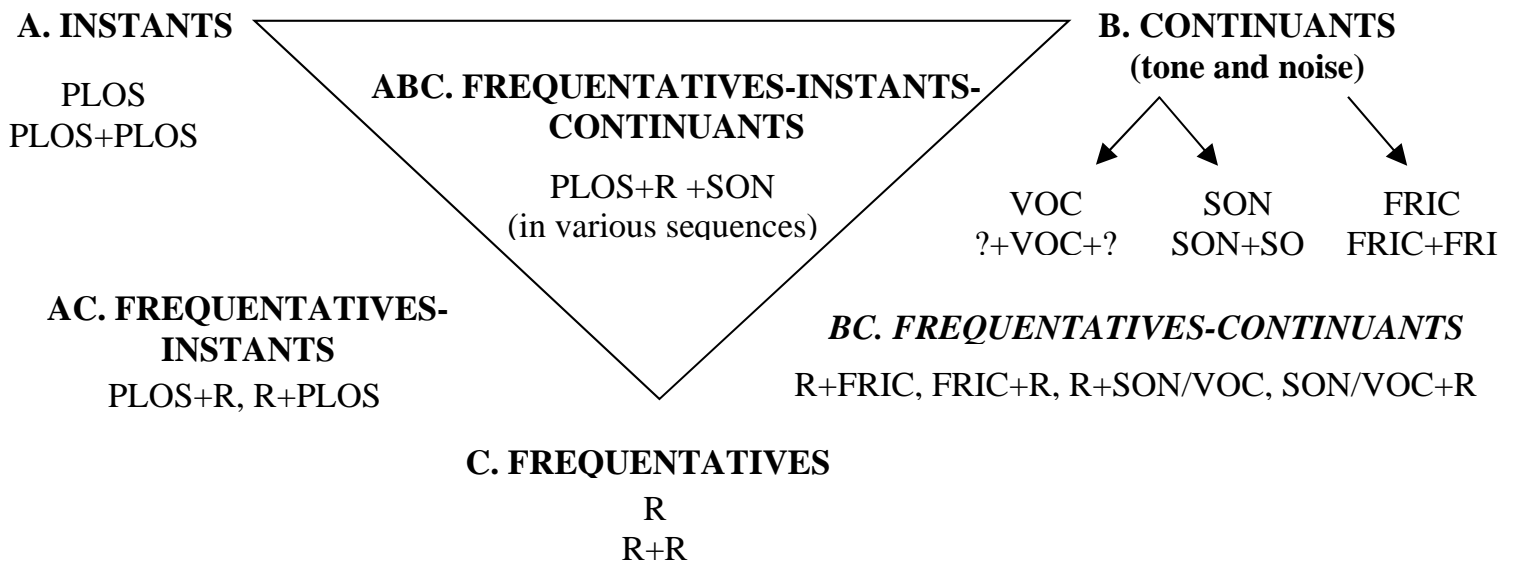

Universal classification of onomatopoeic words revised

Such division solves our problem 1 (the place of frequentatives in the classification). Now all "simple" onomatopoeic words are on the same level (classes) and "complex" ones on another (hyper-classes) - frequentatives-(quasi)-instants and frequentatives-(quasi)-continuants now form hyper-classes of their own (frequentatives-instants and frequentatives-continuants respectively).

The whole system of oppositions is now represented as a continuum with three distinct "peaks" (instants, continuants, and frequentatives), all the "mixed” classes are in the middle.

The Voronin's class “pure frequentatives” (problem 2) with $\mathrm{R}$ in auslaut I unite with frequentatives-instants as it is only a question of distribution but not of quality. This leaves the "square" which is meant for (pure) frequentatives empty. So, what are (pure) frequentatives which should represent (pure) dissonances?

Here I would like to touch upon our problem 4 (structural models do not describe onomatopoeic interjections and polysyllabic imitative words).

I propose to distinguish three different levels of imitation in onomatopoeic words: phonemic, syllabic, and polysyllabic (plus quasi-polysyllabic). Applied to the UCO it this division should take the following form (see Tabl.).

Also, instead of introducing "fixed" models that meticulously describe all (with certain exceptions) onomatopoeic words in the language system - which, however, reflect present-day phonotactic constraints (problems 4 and 5) - I propose introducing a general framework for classification which (1) will be not so "tight" and will incorporate mono-phonemic onomatopoeic interjections and polysyllabic onomatopoeic words and (2) will reduce the number of types and models (solving problem 6). 
ДИСКУРС. 2021. Т. 7, № 1

DISCOURSE. 2021, vol. 7, no. 1

Universal classification of onomatopes applied to words of different length

\begin{tabular}{|c|c|c|c|c|c|c|}
\hline \multirow{3}{*}{$\begin{array}{l}\text { Type of structure / } \\
\text { Typological class }\end{array}$} & \multicolumn{6}{|c|}{ CLASSES } \\
\hline & \multirow{2}{*}{ Instants } & \multicolumn{4}{|c|}{ Continuants } & \multirow{2}{*}{ Frequentatives } \\
\hline & & \multicolumn{2}{|c|}{ Tonal } & \multicolumn{2}{|c|}{ Noise } & \\
\hline phonemic & PLOS & \multicolumn{2}{|c|}{$\mathrm{V} / \mathrm{SON}$} & \multicolumn{2}{|c|}{ FRIC } & $\mathrm{R}$ \\
\hline \multirow{2}{*}{ syllabic } & \multirow{2}{*}{$\begin{array}{l}\text { PLOS }+ \\
\text { PLOS* }\end{array}$} & \multicolumn{2}{|c|}{$(\mathrm{CONS})+\mathrm{V}+(\mathrm{CONS}) / \mathrm{SON}+\mathrm{SON}$} & \multirow{2}{*}{\multicolumn{2}{|c|}{$\begin{array}{r}\text { FRIC+FRIC } \\
\text {; FRIC+SON }\end{array}$}} & \multirow{2}{*}{$\mathrm{R}+\mathrm{R}$} \\
\hline & & \multicolumn{2}{|c|}{ Tone-noise K: SON+FRIC; FRIC+SON } & & & \\
\hline poly-syllabic & $\begin{array}{l}\text { PLOS+PLOS+ } \\
\quad+\text { PLOS... }\end{array}$ & \multicolumn{2}{|c|}{$\mathrm{V}+(\mathrm{CONS})+\mathrm{V}+(\mathrm{CONS})+\mathrm{V} \ldots$ etc. } & \multicolumn{2}{|c|}{ FRIC+FRIC+FRIC... } & $\mathrm{R}+\mathrm{R}+\mathrm{R} \ldots$ \\
\hline \multirow{2}{*}{$\begin{array}{l}\text { Type of structure / } \\
\text { Typological class }\end{array}$} & \multicolumn{6}{|c|}{ HYPER-CLASSES } \\
\hline & IK & FI & \multicolumn{2}{|c|}{ FK } & \multicolumn{2}{|r|}{ FIK } \\
\hline phonemic & - & - & \multicolumn{2}{|c|}{-} & \multicolumn{2}{|r|}{-} \\
\hline syllabic & $\begin{array}{l}\text { PLOS+FRIC; } \\
\text { FRIC+PLOS; } \\
\text { PLOS+SON; } \\
\text { SON+PLOS }\end{array}$ & $\begin{array}{l}\text { R+PLOS; } \\
\text { PLOS+R }\end{array}$ & \multicolumn{2}{|c|}{$\begin{array}{l}\text { R+SON/FRIC; } \\
\text { SON/FRIC +R; } \\
\text { FRIC+R+SON }\end{array}$} & \multicolumn{2}{|c|}{$\begin{array}{c}\text { PLOS+R+SON; } \\
\text { FRIC+R+PLOS; } \\
\text { R+SON+PLOS; } \\
\text { PLOS+R+FRIC etc. } \\
\text { within one syllable }\end{array}$} \\
\hline poly-syllabic & $\begin{array}{l}\text { PLOS+FRIC+ } \\
\text { PLOS etc. }\end{array}$ & $\begin{array}{c}\text { PLOS+R+PLOS } \\
\text { etc. }\end{array}$ & $\mathrm{R}+\mathrm{SON}$ & R etc. & all other & combinations \\
\hline
\end{tabular}

*The schema describes a CVC-syllable type language.

Thus, the classification takes the following form:

\section{(1) Phonemic level.}

On the simplest level only UCO's classes (and not hyper-classes) can be represented:

- instants (one plosive, e. g. KKKK “a crackling sound” [9, p. 83]);

- continuants (one fricative representing a noise, e. g. SH! (cf. SHHHHH "a hushing sound made to quieten someone” [9, p. 124]); or one vowel, e. g EEEE! representing tone (in this case, a high-pitched cry of pain [9, p. 47]);

- frequentatives (one trill (or its equivalent) representing a harsh, dissonant sound, e. g. $R R R$ ! representing the sound of a dog's growl [9, p. 118].

\section{(2) Syllabic level.}

As human language does not consist only of onomatopoeic interjections (they alone are insufficient for describing all possible contexts the language is required in), the next level is that one of syllables. These are onomatopoeic words described by the structural models and they constitute the core of language's imitative lexicon (the discussion of what is a core and what is a periphery of the imitative lexicon - see [10]). This is the level where the coinage is restricted and conditioned by conventional phonemic and phonotactic constraints. In order to form a syllable, one should introduce a vowel (or sonorant) into the structure. This lessens the imitative potential of onomatopoeic words but makes them "proper" words and allows their functioning in a language.

Thus, in a CVC-syllable language instants (I) are onomatopoeic words with two plosives in their structure (E. tap) denoting abrupt pulse-like sounds. In a CV-syllable language the second plosive is dropped.

Continuants (K) are (a) onomatopoeic words with a vowel (or sonant) in their structure denoting prolonged tones (E. hoot); and (b) onomatopoeic words with two fricatives in their structure denoting noises (E. sizz(le)).

Whereas noise continuants resemble instants in their structure, tone continuants should be discussed separately. 
I indicated (problem 10) that a long vowel alone cannot form a basis for distinguishing tone continuants (for the discussion - see Part 1). The ensuing difficulty is distinguishing tonal continuants with CV, CVC, VC syllable structures from words belonging to other classes. That is, is a Russian dydemb [dudet'] "to toot" (root $d u d-$, PLOS+VOC+PLOS) a tonal continuant or an instant? In such cases I propose the following:

- establishing the meaning - dydemb "to toot, to play a flute, to drone" - all descriptions answer to non-abrupt, non-pulse sounds of certain duration (and not an abrupt sound);

- creating minimal phonosemantic pairs with contrast phonemes to model which elements of the onomatopoeic roots would "suffer" most from the substitution (that is, in which case we would coin a word with a very different imitative function) - **tud-et', **dup-et', **did-et'; in these examples the first two could still mean "to toot, to play a flute, to drone", while the third one is more suggestive of a high-pitched sound rather than of that one of a toot or a drone.

Thus, $\partial y \partial e m b$ is a tonal continuant.

The method of minimal pairs applied to phonosemantics I see as a validation instrument for the classification.

The tone-noise continuants (c) also exist. They are a mixture of sonants (render tones) and fricatives (render noises): SON+ FRIC (mash "to beat into a soft mass; to crush"); FRIC + SON (zing "a sharp, high-pitched ringing sound; a twang”).

Frequentatives (F) are onomatopoeic words with two rhotic consonants (or their equivalents) in their structure denoting harsh, dissonance-like sounds (E. roar, OE rarian, Church Slavonic rarŭ "sound" [11]). Here one should remark that trills (and even their equivalents) are typologically less common than plosives which makes the number of syllabic "pure" frequentatives extremely limited (RV, RVR, VR). This is the possible reason why Voronin started looking for another types and structures and included frequentatives-instants and frequentatives-continuants into the frequentative class (problem 1).

Limiting the (syllabic) frequentatives by only three models we solve both problems 1 and 2 . Thus, all onomatopoeic words belonging to class "frequentatives" are rrrr!, roar [ro:] and an obsolete arr "to snarl as a dog".

All words marked in [1] and [3] as "frequentatives" are, in fact, frequentatives of mixed types (with an "instant" or a "continuant" component). Even words labelled as "pure frequentatives" I consider to be a subtype of frequentatives-instants (purr, birr), which solves problem 2.

As for whether to include R-formatives into classification (problem 3), I suggest that one should not, as they are not part of the root and have more or less their own, distinct meaning (see my argumentation in Part 1). Thus, English twit and twitter belong to the same type and hyperclass - instants-continuants, the later with an R-formative indicating a repetitive quality of the sound-based action.

Instants-continuants (IK) are a hyper-class of onomatopoeic words combining elements of pulses and tones/noises. While pulses are rendered by plosives, noises - by fricatives, tones are rendered mostly by sonorants unless a vowel in such word is phonosemantically significant (see the example with dydems above). Pulse and non-pulse elements can appear both in anlaut and auslaut. Thus, we arrive at four combinations for CVC syllable languages (if vowels are not taken into account, plus additional consonants other than $\mathrm{R}$ might be added): 
- PLOS + FRIC (E. buzz "a sibilant hum, such as is made by bees, flies, and other winged insects”); note that I have excluded the voiced / voiceless opposition from the classification making it an additional feature (problem 9);

- FRIC + PLOS (E. zip "a light sharp sound such as that produced by a bullet or other small or slender object passing rapidly through the air”);

- PLOS + SON (bom "the sound caused by the discharge of a gun", bang "a heavy resounding blow, a thump”);

- SON / approximant + PLOS (yip "a sharp, high-pitched ringing sound; a twang”).

Frequentatives-instants (FI) are a hyper-class of onomatopoeic words combining elements of pulses and dissonances. For the syllabic FI I suggest (upon the same grounds as for the IK - if vowels are not taken into account, plus additional consonants other than sonorants might be added) the following frame:

- R + PLOS (crack "a sharp sound caused by the sudden breaking of anything hard");

- PLOS + R (hist. birr "a whirring sound”).

Frequentatives-continuants (FK) are a hyper-class of onomatopoeic words combining elements of pulses and tones or noises. For them I suggest the following general frames:

- R+ SON / FRIC (ring “a ringing sound or noise”, rash (obsol.) "a rustling or scraping noise”);

- SON / FRIC +R (hist. chirr "to make the trilled sound characteristic of grasshoppers"); note that I consider affricates closer to fricatives in their imitative function (problem 7);

- FRIC + R + SON (thrum "an echoic word representing various sounds, esp. the tones produced by 'thrumming' a guitar or similar instrument”).

Again, this is valid if vowels are not taken into account, plus additional consonants other than plosives might be added.

The fourth hyper-class I suggest is frequentatives-instants-continuants (FIK) which combines plosives, sonorants and $\mathrm{R}$ in their complex structure. For example:

- PLOS + R + SON (croon "a low murmuring or humming sound, as of a tune hummed in an undertone");

- PLOS + R + FRIC (crash "a sharp sound caused by the sudden breaking of anything hard”);

- FRIC + R + PLOS (thrump "the sound of a blow");

$-\mathrm{R}+\mathrm{SON}+\mathrm{PLOS}$ (rumble "a low continuous murmuring, grumbling, or growling sound”).

(3) Polysyllabic / quasi-polysyllabic level.

As discussed above (see problem 4), imitative words might consist of several syllables and thus are not described by Voronin. I propose not to extent the classification to this level, as the majority of polysyllabic words (e. g. rum-ti-toom, cock-a-doodle-doo) are rare and unique in their structure.

However, some of them can be uniform (e. g. cuckoo - tonal continuant + tonal continuant), ruru (frequentative-continuant + frequentative-continuant). Only in such cases I deem necessary to classify them as continuants, frequentatives-continuants etc.

Also, I distinguish a quasi-polysyllabic level for onomatopoeic interjections like KKKSH "the sound made by a brick crashing through a window" [9, p. 83]. They do not form syllables in a strict sense - such words as KKKSH are either geminated forms or a series of phonemes with imitative function merged together. 
The majority of onomatopoeic interjections in [9] are predominantly of mixed nature, however, some of them are more or less uniform and it is possible to classify them with certain precision. For example:

- BAPP “a punching sound; a kicking sound" [9, p. 17] is an instant;

- EEE-OOOOOOO “a wailing animal sound” [9, p. 48] is a tone continuant;

- FZSSSSSSSSSS "the sound of champagne fizzing" [9, p. 60] is a noise continuant;

$-R R R R R$ "the sound of motorcycle engines" [9, p. 119] is a frequentative;

- FZZZT "the sound of an object suddenly breaking into flames" [9, p. 61] is an instantcontinuant;

- RATATATAT "the sound of a machine gun" [9, p. 114];

- RRRRAAAAAAA “a sound made by a person straining physically” [9, p. 118] is a frequentative-continuant;

- RRZZTTT "the sound of electronic weapon fire" [9, p. 120] is a frequentative-instantcontinuant.

However, it does not make sense to further classify such onomatopoeic interjections like KARASHBOOMBAM "a sound of people and equipment in operation, as might be heard on a construction site” [9, p. 79] as such words are comprised from smaller easily definable units.

These are some possible solutions to the problems I indicated in the Introduction. The remaining major and yet unsolved problems are:

- What form will frequentatives (pure and of mixed types) take in languages without phonemic R?

- What is the role of voice in onomatopoeia and how it should be reflected in the classification?

- Should a tone (for the tonal languages) be incorporated into the classification?

- What imitative functions will the consonants and vowels not encountered in the studied languages (e. g. non-pulmonic consonants) have?

These questions are still awaiting their researchers.

Conclusion. The Universal Classification has revealed that onomatopoeic words are not a haphazard miscellany of words but form "a patently rigorous system within the framework of language" [12, p. 23]. On the whole, the classification based on types of correspondences with acoustic denotata has proven to be successful. However, some aspects of the UCO require certain revision after the 50 years which have passed since its introduction.

The changes I propose in this article can be briefly summed up as follows:

- distinguishing four hyper-classes of onomatopoeic words instead of two;

- leaving only R/RV(R) type in the class of frequentatives and considering Voronin's "pure” frequentatives as a subtype of frequentatives-instants;

- excluding R-formatives from the classification;

- distinguish three levels of imitation in onomatopoeic words: phonemic, syllabic, and polysyllabic, only the second of which being (partly) described by structural models;

- generalizing and thus reducing the number of structural models on the ground of their being language-specific and reflecting phonotactic constraints which change in diachrony;

- considering affricates equal to fricatives in their imitative function (which transfers a number of Voronin's instants into the hyper-class of instants-continuants); 
- ascribing all sonorants an imitative function of rendering a tonal non-pulse (which also transfers a number of Voronin's instants into the hyper-class of instants-continuants);

- "extracting” voiced / unvoiced distinction from the UCO as an additional, secondary feature, thus reducing the number of structural models.

These proposed changes, as one can see, do not undermine the basic principles of the classification and I hope will ease its implication and reduce the number of contradictions which arise in the course of its implementation on the material of structurally different languages.

\section{ABBREVIATIONS:}
AFFR - affricate
DENT - dental
FI - frequentative-instant
FIK - frequentative-instant-continuant
FRIC - fricative
FRIC $^{\mathrm{v}}$ - voiced fricative
FRIC $^{\Lambda}$ - voiceless fricative
GUTT - guttural
I - instant
IK - instant-continuant
$\mathrm{K}$ - continuant
$\mathrm{L} / \mathrm{H}$ - low/high
LAB - labial
LAT - lateral

NAS - nasal

PLOS - plosive

$\mathrm{R}-\mathrm{a}$ rhotic phoneme (uvular, trill etc.)

$\mathrm{R}_{\mathrm{f}}$ - R-formative

S/W - strong/weak

SD-1 - first de-iconization stage

SD-2 - second de-iconization stage

SD-3 - third de-iconization stage

SD-4 - fourth de-iconization stage

SON - sonant

UCO - Universal Classification of Onomatopoeic words

VŌC - a long vowel

VǑC - a short vowel

\section{REFERENCES}

1. Voronin, S.V. (2006), Osnovy fonosemantiki [The Fundamentals of Phonosemantics], Lenand, Moscow, RUS.

2. Flaksman, M.A. (2015), "Diachronic development of English iconic vocabulary", Can. Sci. (Philol.) Thesis, Saint Petersburg State Univ., SPb., RUS.

3. Voronin, S.V. (2004), Angliiskie onomatopy: fonosemanticheskaya klassifikatsiya [English Onomatopes: a Phonosemantic Classification], Gelikon Plyus, SPb., RUS.

4. Krasnova, A.V. (2018), "Universal and language-specific in Turkish imitative lexicon", Can. Sci. (Philol.) Thesis, St. Petersburg Univ. of Economy, SPb., RUS.

5. Bratus', I.B. (1976), "Acoustic Onomatopes in Indonesian", Abstract Can. Sci. (Philol.) dissertation, Univ. of Leningrad, Leningrad, USSR.

6. Lapkina, L.Z. (1979), "English and Bashkir acoustic onomatopes (experience of typological research)", Can. Sci. (Philol.) Thesis, Univ. of Leningrad, Leningrad, USSR.

7. Kankia, N.D. (1988), "The Primary Motivation of The Word (In English and Georgian)]", Can. Sci. (Philol.) Thesis, Univ. of Leningrad, Leningrad, USSR.

8. Veldi, E.A. (1988), “English-Estonian Parallels in Onomatopoeia”, Can. Sci. (Philol.) Thesis, Univ. of Tartu, Tartu, EST.

9. Taylor, K.J. (2007), KA-BOOM! A Dictionary of Comic Book Words, Symbols and Onomatopoeia, Mora Publications, Surrey, BC, CAN.

10. Flaksman, M.A. (2019), "From IE *ue to English window: on the age and number of imitative words in English", Indo-European Linguistics and Classical Philology-XXIII (Joseph M. Tronsky memorial Conference. Proceedings of the International Conference), in by N.N. Kazansky (ed.), St Petersburg, 2426 June, 2019, Part II, P. 1066-1075. 
11. The Oxford English Dictionary, available at: http://www.oed.com (accessed 25.04.2020).

12. Voronin, S.V. (2005), Iconicity. Glottogenesis. Semiosis: Sundry Papers, St. Petersburg Univ. Press, SPb., RUS.

\section{Information about the author.}

Maria A. Flaksman - Can. Sci. (Philology) (2015), Associate Professor at the Department of Foreign Languages, Saint Petersburg Electrotechnical University, 5 Professor Popov str., St Petersburg 197376, Russia. The author of over 51 scientific publications. Area of expertise: iconicity studies, phonosemantics, onomatopoeia, historical linguistics, etymology, Germanic languages. ORCID: https://orcid.org/0000-0002-8258-4825. E-mail: maria.alexeevna@gmail.com

\section{СПИСОК ЛИТЕРАТУРЫ}

1. Воронин С. В. Основы фоносемантики. М.: Ленанд, 2006.

2. Флаксман М. А. Диахроническое развитие звукоизобразительной лексики английского языка: дис. ... канд. филол. наук / СПбГУ. СПб., 2015.

3. Воронин С. В. Английские ономатопы: фоносемантическая классификация. СПб.: Геликон Плюс, 2004.

4. Краснова А. В. Универсальные характеристики звукоизобразительной лексики и их специфические проявления в турецком языке: дис. ... канд. филол. наук / СПбГЭУ. СПб., 2018.

5. Братусь И. Б. Акустические ономатопы в индонезийском языке: автореф. дис. ... канд. филол. наук / ЛГУ. Л., 1976.

6. Лапкина Л. 3. Английские и башкирские акустические ономатопы (опыт типологического исследования): дис. ... канд. филол. наук / ЛгУ. Л., 1979.

7. Канкия Н. Д. Примарная мотивированность слова (на материале английского и грузинского языков): дис. ... канд. филол. наук / лгУ. л., 1988.

8. Вельди Э. А. Англо-эстонские параллели в ономатопее: дис. ... канд. филол. наук / Тартуский ун-т. Тарту, 1988.

9. Taylor K. J. KA-BOOM! A Dictionary of Comic Book Words, Symbols and Onomatopoeia. Surrey, BC: Mora Publications, 2007.

10. Flaksman M. A. From IE *ue to English window: on the age and number of imitative words in English // Indo-European Linguistics and Classical Philology-XXIII (Joseph M. Tronsky memorial Conference. Proceedings of the International Conference), St Petersburg, 24-26 June, 2019, in N. N. Kazansky (ed.). Part II. P. 635-1208. SPb.: Nauka, 2019. P. 1066-1075.

11. The Oxford English Dictionary. URL: http://www.oed.com (дата обращения: 25.04.2020).

12. Voronin S. V. Iconicity. Glottogenesis. Semiosis: Sundry Papers. SPb.: St. Petersburg Univ. Press, 2005.

\section{Информация об авторе.}

Флаксман Мария Алексеевна - кандидат филологических наук (2015), доцент кафедры иностранных языков Санкт-Петербургского государственного электротехнического университета «ЛЭТИ» им. В. И. Ульянова (Ленина), ул. Профессора Попова, д. 5, СанктПетербург, 197376, Россия. Автор более 51 научной публикации. Сфера научных интересов: фоносемантика, звукоизобразительность, ономатопея, сравнительно-историческое языкознание, этимология, германские языки. ORCID: https://orcid.org/0000-0002-82584825. E-mail: maria.alexeevna@gmail.com 